\title{
ВПЛИВ РОЗВИТКУ КООРДИНАЦІЙНИХ ЗДІБНОСТЕЙ УЧНІВ 15-16-РІЧНОГО ВІКУ НА РІВЕНЬ ЗАСВОСННЯ ПРЯМОГО НАПАДАЮЧОГО УДАРУ У ВОЛЕЙБОЛІ
}

\author{
Олександр Швай${ }^{1}$ Юрій Цюпак ${ }^{1}$, Андрій Ковальчук ${ }^{1}$, Володимир Тарасюк ${ }^{2}$ Леонід Гнітецький \\ ${ }^{1}$ Східноєвропейський національний університет імені Лесі Українки, Луцьк, Україна, oleks0463@gmail.com \\ ${ }^{2}$ Луцький педагогічний коледж, Луцьк, Україна
}

https://doi.org/10.29038/2220-7481-2020-01-96-101

\begin{abstract}
Анотації
Актуальність дослідження зумовлена потребою в розвитку координаційних здібностей школярів 1516-річного віку, що забезпечують їхнє вміння виконувати прямий нападаючий удар у волейболі. Мета дослідження - проаналізувати стан проблеми розвитку координаційних здібностей школярів 15-16-річного віку для покращення засвоєння ними прямого нападаючого удару. Методи дослідження - теоретичний аналіз й узагальнення літературних джерел, педагогічне тестування та педагогічне спостереження, методи математичної статистики. Учасники дослідження. Дослідження проводили на базі ЗОШ № 10 м. Луцька. Під час проведення дослідження задіяно 60 школярів 15-16-річного віку. Дітей та їхніх батьків інформовано про всі особливості дослідження, вони дали згоду на участь в експерименті. Результати дослідження. Після проведення експерименту виявлено, що в контрольній та експериментальній групах відбулися зміни в показниках розвитку координаційних здібностей школярів. Так, в експериментальній групі (ЕГ) вони зросли в межах від 12 до 58 \%, тоді як у контрольній (КГ) - лише в межах 1-9 \%. Результати експертної оцінки володіння учнів прямим нападаючим ударом виявили, що теоретична підготовленість досліджуваних ЕГ підвищилася на 14,5 \% (у КГ - 6 \%); рівень техніки виконання прямого нападаючого удару зріс на 65 \% в ЕГ та лише на 6,5 \% - у КГ; показник контрольного нормативу мав приріст 55 \% в ЕГ, 15 \% - у КГ. Висновки. За результатами експертної оцінки виконання прямого нападаючого удару до й після експерименту можна зробити висновок про ефективність застосування авторської програми розвитку координаційних здібностей школярів для покращення засвоєння ними прямого нападаючого удару.
\end{abstract}

Ключові слова: волейбол, нападаючий удар, фізична підготовленість, технічна підготовленість, координаційна здібність.

Александр Швай, Юрий Цюпак, Андрей Ковальчук, Владимир Тарасюк, Леонид Гнитецкий. Влияние развития координационных способностей учащихся 15-16-летнего возраста на уровень усвоения прямого нападающего удара в волейболе. Актуальность исследования обусловлена потребностью в развитии координационных способностей школьников 15-16-летнего возраста, которые обеспечивают их умение выполнять прямой нападающий удар в волейболе. Цель исследования - проанализировать состояние проблемы развития координационных способностей школьников 15-16-летнего возраста для улучшения усвоения ими прямого нападающего удара. Методы исследования - теоретический анализ и обобщение литературных источников, педагогическое тестирование и педагогическое наблюдение, методы математической статистики. Участники исследования. Исследование проводили на базе школы № 10 г. Луцка. Во время проведения исследования задействовано 60 школьников 15-16-летнего возраста. Дети и их родители осведомлены обо всех особенностях исследования, они дали согласие на участие в эксперименте. Результаты исследования. После проведения эксперимента установлено, что в контрольной и экспериментальной группах произошли изменения в показателях развития координационных способностей школьников. Так, в экспериментальной группе (ЭГ) они выросли в пределах от 12 к 58 \%, тогда как в контрольной (КГ) - только в пределах от 1 \% к 9 \%. Результаты экспертной оценки владения учащимися прямым нападающим ударом обнаружили, что теоретическая подготовленность учащихся ЭГ повысилась на 14,5 \% против 6 \% в КГ; уровень техники исполнения прямого нападающего удара вырос на 65 \% в ЭГ и только на 6,5 \% - в КГ; показатель контрольного норматива имел прирост 55 \% в ЭГ против $15 \%$ - в КГ. Выводы. По результатам экспертной оценки выполнения прямого нападающего удара до и после эксперимента можно сделать вывод об эффективности применения авторской программы развития координационных способностей школьников для улучшения усвоения ими прямого нападающего удара.

Ключевые слова: волейбол, нападающий удар, физическая подготовленность, техническая подготовленность, координационная способность.

Oleksandr Shvai, Yurii Tsiupak, Andrii Kovalchuk, Volodymyr Tarasiuk, Leonid Gnitetskii. The Influence of the Coordination Abilities Development of Pupils at 15-16 Years of Age on the Level of Assimilation of a Direct Attack Hit in Volleyball. Topicality of the study is caused by the need to develop the coordination skills of pupils at 15 
16 of age, which provide their ability to perform a direct volleyball hit. The Purpose of the Research is to analyze the problem of development of coordination abilities of schoolchildren at 15-16 years of age for improving their direct striking hit. The Research Methods are theoretical analysis and generalization of literary sources, pedagogical testing, and pedagogical observation, methods of mathematical statistics. The Participants of the Research. This study was conducted on the basis of Lutsk secondary school № 10. The study involved 60 schoolchildren at 15-16 years of age. The children and their parents were informed about all research features and they agreed to participate in the experiment. The Research Results. After the experiment, it was found that in the control and experimental groups there were changes in the indicators of pupils` coordination abilities development. Thus, in the experimental group (EG) they increased in the range of $12 \%-$ $58 \%$, whereas in the control group (CG) - only in the range of 1-9\%. The results of students' expert review of direct attack hit revealed that theoretical preparedness of the EG students increased by $14,5 \%$ versus $6 \%$ in the CG; the level of direct attack hit technique increased by $65 \%$ in the EG and only by 6,5\% in the CG; the control standard indicator had an increase of $55 \%$ in the EG compared to $15 \%$ in the CG. Conclusions. According to the results of the expert review of the direct attack hit performance before and after the experiment, it can be concluded that the effectiveness of the author's program of the pupils` coordination abilities development for improving their mastery of the direct attacking hit.

Key words: volleyball, attack hit, physical training, technical training, coordination ability.

Вступ. Аналіз спеціальної літератури та узагальнення практичного досвіду свідчать, що волейбол $\epsilon$ доволі популярним засобом фізичного виховання серед учнів середнього й старшого шкільного віку. Це пояснюється значним інтересом дітей до ігрових видів спорту та волейболу зокрема, оскільки участь у них дає можливість не лише реалізувати свою потребу в русі, але й проявити себе через емоційночуттєву сферу. Практика свідчить, що рівень техніко-тактичної підготовленості школярів у волейболі $€$ низьким. На нашу думку, це є результатом того, що вчителі не приділяють увагу детальному вивченню техніки цього технічного елементу, тобто не дають учням чітких рекомендацій щодо вдосконалення їхнього рівня розвитку координаційних здібностей та інших, не менш вагомих для виконання обговорюваної рухової дії фізичних якостей. Усі елементи техніки виконуються учнями з грубими порушеннями, тому сама гра перетворюється на елементарне утримування м'яча в повітрі. Тому можна дійти висновку, що існує потреба у вдосконаленні рівня виконання всіх технічних елементів у волейболі та прямого нападаючого удару зокрема $[3 ; 5 ; 8]$.

Прямий нападаючий удар є чи не найскладнішим елементом техніки гри у волейбол. Правильне його виконання забезпечує видовищність волейболу та викликає захоплення в школярів. Утім, учні не володіють технікою цього складнокоординаційного елементу. Однією з причин такого явища є недостатній розвиток координаційних здібностей школярів, що визначають якість засвоєння техніки прямого нападаючого удару. Також оскільки учні не здатні повною мірою досягнути високого рівня володіння технікою прямого нападаючого удару, знижується їхній інтерес до цієї захопливої гри [2; 3; $4 ; 12]$.

Мета дослідження - проаналізувати стан проблеми розвитку координаційних здібностей школярів 15-16-річного віку для покращення засвоєння ними прямого нападаючого удару.

Матеріал та методи дослідження. Дослідження проводили на базі ЗОШ № 10 м. Луцька. Задіяно 60 школярів 15-16-річного віку $(\mathrm{n}=60)$. Дітей та їхніх батьків проінформовано про всі особливості дослідження, вони дали згоду на участь в експерименті.

У контрольній (КГ) та експериментальній (ЕГ) групах було по тридцять учнів десятих класів. У контрольній групі уроки проводили без акценту на розвиток координаційних здібностей. В ЕГ застосовували авторську програму для розвитку загальних, спеціальних і специфічних координаційних здібностей. Під час визначення переліку координаційних здібностей ми керувалися класифікацією, запропонованою В. М. Платоновим та М. М. Булатовою [11].

Для визначення рівня розвитку координаційних здібностей використовувалася батарея тестів: диференціація просторових і часових характеристик - учасник тестування пробігає 30 м із максимальною швидкістю, час фіксується 3 точністю до 0,1 с. Потім повторює вправу 3 розміщеними на дистанції 11 гімнастичними обручами. По три на старті й на фініші, п’ять - на середині дистанції. Оцінка: різниця часу між 1 і 2 забігами; відтворення динамічних характеристик - виконується стрибок у довжину з місця 3 оптимальним зусиллям. Потім відтворити результат тричі $з$ тим самим показником довжини. Експериментатор розраховує 25 \%, 50 \%, 75 \% від першого результату, а обстежуваний відтворює в стрибках розраховані величини. Оцінка: розраховують середній показник довжини похибки; оцінка просторових характеристик - обстежуваний стоїть спиною до набивного м'яча (з умовною назвою «Мітка»), за яким на відстані 3 м і 1,5 м один від одного лежать у колах п’ять набивних м'ячів з номерами (нумерація довільна). Експериментатор називає цифру, учень повертається на $180^{\circ}$, біжить 
до названого номера м'яча, торкається його рукою й повертається до лінії старту, де розміщена «Мітка», торкається іiі, у цей час експериментатор називає наступну цифру - і вправа продовжується ще двічі. Оцінка: визначається час виконання з точністю до 0,1 с. Для кожного учня розстановка м'ячів змінюється; здатність узгоджувати рухи в руховій дії - виконується задана вправа. Оцінка: порушення узгодженості й послідовності виконання вправи (кількість помилок; здатність утримувати динамічну рівновагу - стоячи на вузькій поверхні гімнастичної лави, учасник тестування виконує чотири повороти (праворуч і ліворуч). Вправа закінчується, коли обстежуваний повертається у вихідне положення. Оцінка: визначається час виконання чотирьох поворотів. Вони дали змогу установити, на якому рівні перебуває розвиток координаційних здібностей на відповідному етапі педагогічного експерименту.

Для визначення компетенцій володіння учнями технікою прямого нападаючого удару на шостому році навчання варіативного модуля «Волейбол» розроблено технологію оцінювання з урахуванням критеріїв, запропонованих МОН молоді та спорту України [10], що передбачає комплексний підхід до оцінювання досягнень учнів: знань, володіння технікою контрольної вправи та кількісного показника під час складання контрольного нормативу. Уроки в контрольній та експериментальній групах проводилися за однакових умов.

Експеримент тривав протягом 2018-2019 рр. й охоплював два етапи науково-педагогічного пошуку. На першому проводився констатувальний експеримент, під час якого проведено тестування КЗ школярів та експертна оцінка рівня володіння прямим нападаючим ударом. На другому етапі відбувалося проведення педагогічного експерименту з упровадженням програми розвитку КЗ, перевірялася ii ефективність, уносилися корективи. Експериментальна методика передбачала випереджувальний розвиток загальних координаційних здібностей. На вивчення варіативного модуля «Волейбол» відведено 10 годин, цьому модулю передували такі: «Легка атлетика», «Баскетбол». Ураховуючи це, в експериментальній методиці розвиток загальних КЗ відбувався засобами легкої атлетики, спортивних ігор, естафет та рухливих ігор, аби забезпечити випереджувальний розвиток координаційних здібностей, що $є$ вагомим під час вивчення прямого нападаючого удару. На всіх уроках із варіативних модулів, що передували волейболу, відбувалося вдосконалення саме таких здібностей, що необхідні для вивчення прямого нападаючого удару. На кожному уроці розвиток загальних координаційних здібностей відбувався в підготовчій та завершальній частинах. Виконувалися такі вправи, що збагачували фонд життєво важливих умінь і навичок, збільшували руховий досвід. Але й в основній частині уроку ми також пропонували відповідні засоби. Утім, це відбувалося в умовах дефіциту часу, оскільки в цій частині уроку розв язувались основні завдання конкретного заняття. У методиці розвитку КЗ школярів головним методичним прийомом була новизна вправ, неочікуваність наступних дій.

Статистичний аналіз результатів експериментального дослідження здійснено за допомогою програми STATISTICA V.6.0 (StatSoft, USA). Результати подано як середнє значення \pm стандартне відхилення $(\mathrm{M} \pm \sigma)$. При нормальному розподілі кількісних перемінних для порівняння 2-х груп застосовували t-тест Стьюдента для незалежних категорій.

Результати дослідження. Біомеханічний аналіз прямого нападаючого удару виявив, що учень повинен володіти комплексом координаційних здібностей, серед них - оцінювати просторово-часові характеристики, просторові характеристики; диференціювати просторово-часові характеристики; диференціювати просторові, динамічні характеристики, координацію рухів, здатність до довільного розслаблення м'язів, спроможність утримувати рівновагу $[1 ; 8 ; 9 ; 11 ; 14]$.

Аналіз результатів дослідження тестувань рівня розвитку координаційних здібностей десятикласників на початку експерименту не виявив достовірних розбіжностей $(\mathrm{p}>0,05)$ між показниками рівня розвитку КЗ учнів експерементальної та контрольної груп (табл.1).

Аналіз результатів тестування на початок експерименту засвідчив, що рівень розвитку здібності до диференціації просторових і часових характеристик руху в учасників ЕГ у середньому становив $1,2 \pm 0,02$ с, а в учнів КГ цей показник виявився дещо кращим і дорівнював $1,1 \pm 0,03$ с. У КГ здібність до відтворення динамічних характеристик становила $23 \pm 0,26$ см, натомість в ЕГ рівень розвитку цієї здібності певною мірою нижчий $-24 \pm 0,26$ см .

Показники досконалості здібності до оцінки просторових характеристик руху виявився на рівні $10 \pm 0,03$ с у КГ та $10 \pm 0,2$ с в ЕГ, перебуваючи фактично на одному рівні. Визначивши стан розвитку здібності до узгодження рухів у рухові дії, у КГ ми виявили, що учні під час виконання контрольної вправи допустили в середньому $6 \pm 0,21$ помилки; в ЕГ цей самий показник дещо гірший - 
$7 \pm 0,22$ помилки. Здібність до утримання рівноваги в учасників КГ виявилася на рівні 7,2 $\pm 0,03$ с, а в ЕГ ця величина становила 7,3 $\pm 0,03$ с.

Рівень розвитку координаційних здібностей учнів 15-16-річного віку на початку експерименту

\begin{tabular}{|c|c|c|c|c|c|}
\hline Координаційна здібність & Група & $\mathbf{M}$ & $\mathbf{M} \pm \mathbf{m}$ & $\sigma$ & $\mathbf{P}$ \\
\hline \multirow{2}{*}{$\begin{array}{c}\text { Диференціація просторових і часових } \\
\text { характеристик, } c\end{array}$} & K & 1,1 & 0,03 & 0,16 & $p>0,05$ \\
\hline & $\mathrm{E}$ & 1,2 & 0,02 & 0,16 & $p>0,05$ \\
\hline \multirow{2}{*}{ Відтворення динамічних характеристик, $с м$} & K & 23 & 0,26 & 1,44 & $\mathrm{p}<0,05$ \\
\hline & E & 24 & 0,26 & 0,47 & $p>0,05$ \\
\hline \multirow{2}{*}{ Оцінка просторових характеристик, $c$} & K & 10 & 0,03 & 0,2 & $p>0,05$ \\
\hline & $\mathrm{E}$ & 10 & 0,2 & 0,16 & $p>0,05$ \\
\hline \multirow{2}{*}{$\begin{array}{c}\text { Узгодження рухів у рухових діях, кількість } \\
\text { помилок }\end{array}$} & K & 6 & 0,21 & 1,15 & $p>0,05$ \\
\hline & $\mathrm{E}$ & 7 & 0,22 & 1,24 & $p>0,05$ \\
\hline \multirow{2}{*}{ Утримання рівноваги, $c$} & K & 7,2 & 0,03 & 0,18 & $p>0,05$ \\
\hline & $\mathrm{E}$ & 7,3 & 0,03 & 0,18 & $p>0,05$ \\
\hline
\end{tabular}

Примітка. граничне $=2,01$ при р $<0,05$.

Для перевірки ефективності впровадження експериментальної методики розвитку координаційних здібностей у навчально-виховний процес і з метою визначення зрушень у показниках рівня розвитку координаційних здібностей та рівня засвоєння учнями прямого нападаючого удару в школярів досліджених груп проведено повторне тестування. Результати дослідження засвідчують, що показники рівня розвитку координаційних здібностей покращилися, як в експериментальній, так і в контрольній групах. Проте в експериментальній групі показники вищі, ніж у контрольній (табл. 2).

\section{Рівень розвитку координаційних здібностей учнів 15-16-річного віку в кінці експерименту}

\begin{tabular}{|c|c|c|c|c|c|c|}
\hline Координаційна здібність & Група & $\mathbf{M}$ & $\mathbf{M} \pm \mathbf{m}$ & $\sigma$ & $\mathbf{p}$ & Приріст, \% \\
\hline \multirow{2}{*}{$\begin{array}{c}\text { Диференціація просторових і часових } \\
\text { характеристик, } c\end{array}$} & $\mathrm{~K}$ & 1 & 0,02 & 0,17 & $\mathrm{p}>0,05$ & 9 \\
\cline { 2 - 7 } & $\mathrm{E}$ & 0,7 & 0,02 & 0,15 & $\mathrm{p}<0,05$ & 42 \\
\hline $\begin{array}{c}\text { Відтворення динамічних } \\
\text { характеристик, } c м\end{array}$ & $\mathrm{~K}$ & 22 & 0,33 & 1,8 & $\mathrm{p}<0,05$ & 4,5 \\
\cline { 2 - 7 } & $\mathrm{E}$ & 16 & 0,3 & 1,6 & $\mathrm{p}<0,05$ & 34 \\
\hline \multirow{2}{*}{ Оцінка просторових характеристик, $c$} & $\mathrm{~K}$ & 9,9 & 0,05 & 0,3 & $\mathrm{p}>0,05$ & 1 \\
\cline { 2 - 7 } & $\mathrm{E}$ & 8,8 & 0,05 & 0,3 & $\mathrm{p}<0,05$ & 12 \\
\hline Узгодження рухів у рухових діях, \\
кількість помилок & $\mathrm{K}$ & 5,6 & 0,15 & 0,8 & $\mathrm{p}>0,05$ & 7 \\
\cline { 2 - 7 } & $\mathrm{E}$ & 3 & 0,2 & 1,05 & $\mathrm{p}<0,05$ & 58 \\
\hline \multirow{2}{*}{ Утримання рівноваги, $c$} & $\mathrm{~K}$ & 7,1 & 0,02 & 0,14 & $\mathrm{p}>0,05$ & 1,5 \\
\cline { 2 - 6 } & $\mathrm{E}$ & 6,1 & 0,04 & 0,2 & $\mathrm{p}<0,05$ & 17 \\
\hline
\end{tabular}

У школярів експериментальної групи покращилися результати за всіма показниками рівня розвитку координаційних здібностей. Так, в учнів екпериментальної групи в кінці експерименту середньостатистичний показник рівня здібності до диференціації просторових і часових параметрів становив $0,7 \pm 0,02$ с, приріст результату відбувся на $42 \%$; під час виконання нормативу на виявлення

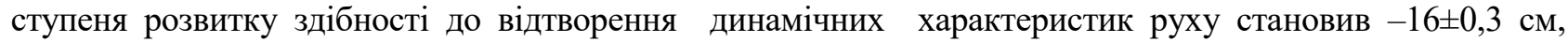
приріст результату відбувся на $34 \%$; рівень розвитку здібності до оцінки просторових характеристик

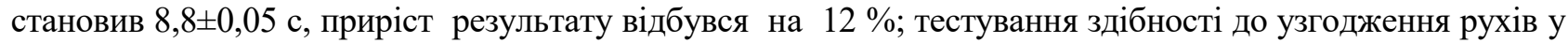
руховій дії показало значні покращення результатів іiі розвитку з $7 \pm 0,22$ помилки до $3 \pm 0,2$ і приріст

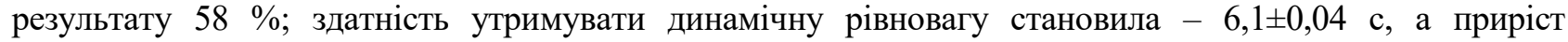
результату $-17 \%$. 
Школярі контрольної групи в кінці експерименту відповідно покращили свої результати: рівень

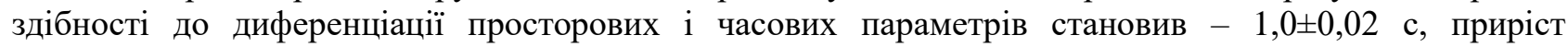
результату - лише на $9 \%$; під час виконання нормативу на виявлення ступеня розвитку здібності до відтворення динамічних характеристик руху становив $-22 \pm 0,3 \mathrm{~cm}$, приріст результату відбувся

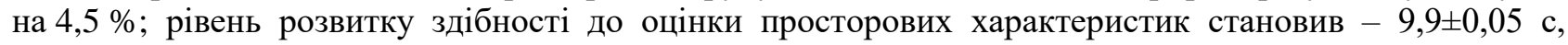
а приріст результату $-1 \%$; тестування здібності до узгодження рухів у руховій дії $-5,6 \pm 0,15$ помилки, приріст результату $-7 \%$; здатність утримувати динамічну рівновагу $-7,1 \pm 0,02$ с, приріст результату $-1,5 \%$.

Дискусія. Численними дослідженнями встановлено, що розвивати КЗ школярів можна в будь-якій частині уроку. Завдання уроку щодо розвитку спеціальних КЗ виконувалися на початку або в середині основної частини уроку за винятком здібності до довільного розслаблення м'язів [8; 9;15]. Результати дослідження значно розширюють дані про розвиток КЗ як частини фізичної підготовки школярів, які потрібні для засвоєння прямого нападаючого удару у волейболі. На жаль, у науково-методичній літературі цьому питанню приділяється недостатньо уваги. Відтак можемо стверджувати, що в нинішній ситуації у сфері фізичної культури запропонована методика розвитку КЗ $є$ актуальною, адже нове покоління дітей бажає чогось нового. Школярі потребують як зовнішніх, так і внутрішніх стимулів щодо занять фізичною культурою й спортом, зокрема волейболом.

Висновки та перспективи подальших досліджень. Отже, результати наших досліджень свідчать, що спеціально підібрана методика використання програми розвитку КЗ найкраще вплинула як на рівень розвитку координаційних здібностей, так і на рівень засвоєння прямого нападаючого удару школярами 15-16 років. Після проведення експерименту виявлено, що як у КГ, так і в ЕГ відбулися зміни в показниках розвитку КЗ школярів. Так, в ЕГ вони зросли в межах від 12 до 58 \%, тоді як у КГ лише в межах від 1 до $9 \%$. Результати експертної оцінки володіння учнями прямим нападаючим ударом виявили, що теоретична підготовленість членів ЕГ підвищилася на 14,5 проти 6 \% у КГ; рівень техніки виконання прямого нападаючого удару зріс на 65 \% в ЕГ і лише на 6,5 \% у КГ; показник контрольного нормативу мав приріст 55 \% в ЕГ проти $15 \%$ у КГ.

Подальші дослідження вбачаємо у вивченні індивідуалізації й творчого підходу до кожного учня при застосуванні спеціальних вправ, необхідних для розвитку координаційних здібностей для засвоєння та виконання ними прямого нападаючого удару у волейболі.

\section{Джерела та література}

1. Бойчук Р. І. Розвиток координаційних здібностей юних волейболістів на етапі початкової підготовки: автореф. дис. ... канд. наук з фіз. вих. та спорту. Київ, 2012. 19 с.

2. Галицька А. Значення та класифікація координаційних здібностей у фізичній підготовці волейболістів. Фізичне виховання, спорт і культура здоров'я у сучасному суспільстві. 2016. № 3(35). С. 91-95.

3. Грабик Н. Засоби розвитку координаційних здібностей могулістів. Молода спортивна наука Украӥни. 2007. Вип. 11. Т. 3. С. 104-109.

4. Грінченко І. Б. Основні методи фізичної підготовки юних волейболістів. Педагогіка, психологія та медико-біологічні проблеми фізичного виховання і спорту. 2000. № 24. С. 8-12.

5. Двейрена О. Перенос координационных способностей: методологический аспект. Олімпійський спорт та спорт для всіх: проблеми здоровя та рекреації, спортивної медицини та реабілітації: зб. матеріалів IV міжнар. наук. конгресу. Київ, 2000. С.120.

6. Кічук С. Ф. Методичні аспекти навчання техніки гри у волейбол. Тернопіль: ТНПУ, 2004. 60 с.

7. Кириченко В. Порівняльний аналіз специфічних проявів координаційних здібностей хлопчиків та дівчаток основної школи. Фізичне виховання, спорт і культура здоров'я у сучасному суспільстві. 2016. 4(28). C. $65-69$.

8. Лях В. И. Совершенствование специфических координационных способностей. Физическая культура в школе. 2000. № 2. С. 7-14.

9. Лях В. И. Координационные способности школьников. Физическая культура в школе. 2000. № 4-5. С. 6$13 ; 3-5$.

10. Навчальна програма 3 фізичної культури для 10-11 класів загальноосвітніх шкіл, затверджена Наказом Міністерства освіти і науки № 1407 від 23 жовт. 2017 р.

11. Платонов В. М., Булатова М. М. Фізична підготовка спортсмена. Київ: Олімп. літ., 1995. 320 с.

12. Устінова Т. Б., Прекурат О. О. Методика розвитку координаційних здібностей юних волейболістів. Педагогіка, психологія та медико-біологічні проблеми фізичного виховання і спорту. 2009. № 8. С. 153-156.

13. Фізична культура в школі: 5-11 класи: метод. посіб. / [за заг. ред. С. М. Дятленка]. Київ: Літера ЛТД, 2011.368 c. 
14. Швай О., Поляковський В., Гнітецький Л., Приступа Є. Роль швидкісно-силових здібностей у формуванні технічної підготовки волейболістів 10-14 років. Фізичне виховання спорт $і$ культура, здоров я у сучасному суспільстві. 2011. № 1(13). С. 73-76.

15. Щирба В. Проблема розвитку швидкісно-координаційних здібностей старших школярів. Фізичне виховання, спорт і культура здоров'я у сучасному суспільстві. 2019. № 4(48). С. 82-87.

\section{References}

1. Boichuk, R. I. (2012). Rozvytok koordynatsiinykh zdibnostei yunykh voleibolistiv na etapi pochatkovoi pidhotovky [Development of coordination skills of young volleyball players at the initial stage of training]: avtoref. dys. ... kand. nauk z fiz. vykh. ta sportu. Kyiv, 19.

2. Halytska, A. (2016). Znachennia ta klasyfikatsiia koordynatsiinykh zdibnostei u fizychnii pidhotovtsi voleibolistiv [The value and classification of coordination skills in the physical training of volleyball players] Fizychne vykhovannia, sport i kultura zdorovia u suchasnomu suspilstvi, no. 3(35), 91-95.

3. Hrabyk, N. (2007). Zasoby rozvytku koordynatsiinykh zdibnostei mohulistiv [Means of development of athletes` coordination abilities]. Moloda sportyvna nauka Ukrainy, Vyp. 11, T. 3, 104-109.

4. Hrinchenko, I. B. (2000). Osnovni metody fizychnoi pidhotovky yunykh voleibolistiv [Basic methods of physical training of young volleyball players]. Pedahohika, psykholohiia ta medyko-biolohichni problemy fizychnoho vykhovannia i sportu, no. 24, 8-12.

5. Dveirena, O. (2000). Perenos koordynatsyonnykh sposobnostei: metodolohycheskyi aspect [Transfer of coordination abilities: methodological aspect]. Olimpiiskyi sport ta sport dlia vsikh: problemy zdorovia ta rekreatsii, sportyvnoi medytsyny ta reabilitatsii: zb.materialiv IV mizhnar.nauk.konh, Kyiv, 120.

6. Kichuk, S. F. (2004). Metodychni aspekty navchannia tekhniky hry u voleibol [Methodical aspects of learning the volleyball technique]. Ternopil: TNPU, 60.

7. Kirichenko, V. (2016). Porivnialnyi analiz spetsyfichnykh proiaviv koordynatsiinykh zdibnostei khlopchykiv ta divchatok osnovnoi shkoly [Comparative analysis of specific manifestations of boys and girls' coordination abilities of primary school]. Fizychne vykhovannia, sport i kultura zdorovia u suchasnomu suspilstvi], no. 4 (28), 65-69.

8. Porivnialnyi analiz spetsyfichnykh proiaviv koordynatsiinykh zdibnostei khlopchykiv ta divchatok osnovnoi shkoly. Fizychne vykhovannia, sport i kultura zdorovia u suchasnomu suspilstvi, 2016, 4(28), 65-69.

9. Liakh, V. I. (2000). Sovershenstvovaniie spetsyfycheskikh koordynatsionnykh sposobnostei [Improving of specific coordination abilities]. Fizycheskaia kultura $v$ shkolie, no. 2, 7-14.

10. Liakh, V. I. (2000). Koordynatsyonnyie sposobnosti shkolnikov [Coordination abilities of schoolchildren]. Fizycheskaia kultura $v$ shkolie, no. 4-5, 6-13; 3-5.

11. Navchalna prohrama z fizychnoi kultury dlia 10-11 klasiv zahalnoosvitnikh shkil, zatverdzhena Nakazom Ministerstva osvity i nauky no. 1407 vid 23 zhovtnia 2017 roku [Physical Education Curriculum for Grades of 10-11, approved by the Oder of Ministry of Education and Science No. 1407 since October 23, 2017].

12. Platonov, V. M., Bulatova, M. M. (1995). Fizychna pidhotovka sportsmena [Physical training of the athlete], Kyiv: Olimpiiska literatura, 320.

13. Ustinova, T. B., Prekurat, O. O. (2009). Metodyka rozvytku koordynatsiinykh zdibnostei yunykh voleibolistiv [Methodology of development of coordination skills of young volleyball players]. Pedahohika, psykholohiia ta medyko-biolohichni problemy fizychnoho vykhovannia i sportu, no. 8, 153-156.

14. Diatlenko, S. M. (2011). Fizychna kultura v shkoli: 5-11 klasy: metodychnyi posibnyk [za zahalnoiu redaktsiieiu S. M. Diatlenka] [Physical education at school: 5-11 forms: methodological text-book], Kyiv: Litera LTD, 368.

15. Shvai, O., Poliakovskyi. V., Hnitetskyi, L., Prystupa, Ye. (2011). Rol shvydkisno-sylovykh zdibnostei u formuvanni tekhnichnoi pidhotovky voleibolistiv 10-14 rokiv [The role of speed-power abilities in the formation of technical training of volleyball players at 10-14 years of age]. Fizychne vykhovannia sport $i$ kultura, zdorov`ia u suchasnomu suspilstvi, no. 1(13), 73-76.

16. Shchyrba, V. (2019). Problema rozvytku shvydkisno-koordynatsiinykh zdibnostei starshykh shkoliariv [The problem of development of high-speed coordination skills of high school children]. Fizychne vykhovannia, sport $i$ kultura zdorovia u suchasnomu suspilstvi, no. 4(48), 82-87.

Стаття надійшла до редакції 28.02.2020 р. 